\title{
ПРОБЛЕМИ СУЧАСНОЇ СИСТЕМИ БУДІВНИЦТВА НОВОГО ЖИТЛА
}

\section{Рецензент - доктор економічних наук, професор А. О. Пантелеймоненко}

Розглянуто окремі проблеми сучасної системи будівництва нового житла, їх висвітлення у світовій економічній літературі. Здійснено аналіз досліджень, присвячених названій темі. Акцентовано увагу на тому, щзо частина проблем під час будівництва нового житла - високі ціни, корупція під час виділення земельних ділянок, реалізачія забудовниками різних «тіньових» схем для итучного збільшення собівартості житла, відсутність контролю з боку покупців за иільовим використанням коштів, система замовників, неврахування потреб певних категорій населення, - може бути вирішена через механізм житлової коопераиіï.

Ключові слова: новобудова, квартира, житло, корупція, хабар.

Постановка проблеми. Існуюча система будівництва житла в Україні має суттєві проблеми і недоліки. Висока вартість будівництва, низька купівельна спроможність значної частини населення. Справи ускладнює втрата Україною Автономної Республіки Крим, значне погіршення економічної ситуації внаслідок бойових дій у зоні проведення антитерористичної операції на Донбасі, різка девальвація національної валюти, високий рівень інфляції. В умовах підвищення цін на будівельні матеріали, пальне, транспортні послуги забудовники підвищують ціни на нове житло. Але чи завжди це підвищення адекватне зростаючим витратам забудовників? Які основні проблеми сучасної системи будівництва нового житла? Відповіді на такі питання намагається запропонувати представлена наукова робота.

Аналіз останніх досліджень і публікацій, у яких започатковано розв'язання проблеми. Дослідження, присвячені названій темі, вже проводилися. Однак відображають вони лише окремі аспекти сучасної системи будівництва нового житла. Так, П. Костицин [1] аналізує основні тенденції на ринку нерухомості, Н. Рева [2] співставляє вартість житла i доходи населення, О. Дубенська [3] розглядає динаміку цін на житло, К. Новосвітня [4] представляє інтерв'ю $з$ колишнім київським міським головою.

Проте немає узагальнення i глибокого комплексного аналізу вітчизняними науковцями основних проблем сучасної системи будівництва нового житла. Саме це й визначає актуальність даної статті.

Мета дослідження: аналіз ситуації на ринку будівництва нового житла для пошуку механізмів вирішення сучасної житлової проблеми в Україні.

Найважливішим завданням дослідження $\epsilon$ аналіз факторів, що спричиняють високу вартість нового житла, визначення основних проблем, що виникають під час будівництва нового житла.

Матеріали та методи дослідження. Для досягнення поставленої мети використані принципи системного аналізу економічних процесів. Для побудови логіки та структури роботи застосовувалися методи структурно-логічного, історико-ретроспективного та причинно-наслідкового аналізу. Методи комплексного та системного підходу застосовувалися для формулювання висновків.

Результати досліджень. Проаналізуємо ситуацію, що склалася на ринку будівництва нового житла в одному з обласних центрів центральної України - у м. Полтава. Тут, станом на жовтень 2014 р., будівництво багатоповерхових житлових будинків здійснювали 5 будівельних фірм: «Будінвест», «Ельман», «Новобуд-2004», Полтавський домобудівельний комбінат, «Полтаватрансбуд». Для простоти розрахунків розглянемо не весь спектр запропонованих квартир, а лише можливість покупки найбільш ходових - однокімнатних квартир.

Найдешевша однокімнатна квартира, запропонована будівельними організаціями для продажу, була розташована на околиці міста, у селі Щербані коштувала 258000 грн., а найдорожча у центральній частині міста - 864000 гривень.

Враховуючи рівень середньої заробітної плати по країні в жовтні 2014 р. - 3509 грн. на місяць [5], житель міста повинен від 6 до 20,5 років повністю заощаджувати свою заробітну плату для придбання однокімнатної квартири, відмовляючись від будь-яких інших витрат. Ми вирахували так званий індекс недоступності житла (співвідношення середньої вартості квартири до середньої заробітної плати, який дорівнює кількості 


\section{EKOHOMIKA}

років, сума зарплат, необхідних для купівлі квартири) у м. Полтава. Можливо ситуація в інших регіонах краща?

На початку 2014 р. індекс недоступності житла у м. Києві був від 7 до 16,4 в залежності від типу житла [2]. Для коректності співставлення зазначених індексів міст Полтави та Києва (синхронізуємо час покупки, врахуємо офіційну середню зарплату по м. Києву, середню площу квартири) вирахуємо індекс недоступності житла у столиці у жовтні 2014 р. для однокімнатної квартири. За основу розрахунку беремо квартиру площею 40 кв. метрів, середню зарплату киянина за жовтень - 5427 грн. Середня вартість квартири 892400 гривень. За заробітної плати 65124 грн. на рік $(5427 * 12)$ індекс недоступності складе 13,7 , тобто середньостатистичному мешканцю Києва для того, щоб купити квартиру, необхідно працювати близько 14 років, нічого не витрачаючи. Якщо ж виходити з європейської практики розрахунку індексу недоступності, де за основу береться квартира в новобудові площею 70 кв. метрів то цифра вже буде інша - 21,5 [2].

Значний «внесок» у збільшення вартості квадратного метру нового житла можуть вносити підрядні організаціі, що задіяні у зведенні будинку, бо існуюча система житлового будівництва дозволяє реалізовувати забудовникам різні «тіньові» схеми, штучно збільшуючи собівартість житла.

Будівельні організації доводять громадськості, що працюють 3 мінімальним прибутком, а висока вартість нового житла є наслідком його високої собівартості, що, в свою чергу, є результатом подорожчання будівельних матеріалів, транспортних послуг, оформлення дозвільних документів на земельні ділянку та зведення будинку. Частково $з$ цими переконаннями можна погодитись.

Але це не завжди відповідає дійсності. Непоодинокі факти, коли забудовники через власні, так звані «карманні» підрядні організації збільшують собівартість житла (отримуючи значні прибутки через такі фірми), або діє система «відкатів» - купуючи будівельні послуги чи будівельні матеріали за завищеними цінами, керівництво будівельних організацій отримує за це «винагороду»- хабаря.

Особливо це характерно для будівельних компаній, власники яких не тільки фізичні особи, а й органи місцевої влади. Працюючи над статтею, автор спілкувався 3 представниками підрядних організацій, які на умовах конфіденційності озвучували конкретні оборудки та суми.

Махінації стосуються не тільки цінових параметрів, але й технічних характеристик матеріа- лів, що використовуються під час будівництва. На прохання автора дослідження знайомий досвідчений представник комерційної структури, що займається монтажем пластикових вікон i дверей, проаналізував їх якість (вікна й двері в приміщенні під магазин на 1-му поверсі) в одній 3 новобудов міста Полтави, що зводилася відомою у місті будівельною фірмою.

Виявилося, якщо якість самого матеріалу (пластику) є задовільною (ціна - середня на ринку), то якість фурнітури (петлі, замки, ручки) низька (китайський виробник, ціна - одна 3 найдешевших).

Звісно, що покупці квартир, офісних чи магазинних приміщень (на перших поверхах багатоквартирних будинків) в умовах нинішньої системи житлового будівництва не можуть контролювати ні якість будівельних матеріалів, ні якість самого будівництва.

Збільшує вартість нового житла й існуюча система замовників. Тобто впливові організації (наприклад, обласні управління міністерства внутрішніх справ, служби безпеки, прокуратури) виступають замовниками будівництва багатоквартирного будинку. «Тиснуть» на органи місцевої влади, отримують земельну ділянку для будівництва.

Далі такий замовник шукає забудовника (будівельну організацію, що має відповідні дозволи на будівництво) і вже забудовник створює фонд фінансування будівництва та здійснює зведення будинку, іноді підключаючи до цього цілу низку підрядних і субпідрядних організацій.

Роль замовника зводиться на початковому етапі до вміння отримати цікаву земельну ділянку (як правило, в центральній частині міста, 3 наявною інженерною мережею), а на завершальній стадії - замовник допомагає забудовнику успішно прийняти будинок в експлуатацію. За все це забудовник отримує кілька квартир в новому будинку (зазвичай безкоштовно).

Водночас забудовник не несе збитків - вартість квартир, що передаються замовнику розподіляється на решту покупців квартир у даному будинку, суттєво збільшуючи ціну квартири.

Рідкістю є випадки, коли замовник у повній мірі оплачує ті квартири, що йому передаються.

Також збільшує вартість житла і багаторічна практика передачі частини квартир у новому житловому будинку для потреб міських виконавчих комітетів.

Значною проблемою $є$ невелика кількість забудовників і відсутність через це жорсткої конкуренції між ними. 
EKOHOMIKA

Основні умови покупки однокімнатної квартири ум. Полтава (станом на жовтень 2014 р.)

\begin{tabular}{|c|c|c|c|c|c|}
\hline \multirow{2}{*}{ Назва підприємства } & \multirow{2}{*}{$\begin{array}{c}\text { Адреса об'єкта } \\
\text { будівництва }\end{array}$} & \multirow{2}{*}{$\begin{array}{c}\text { Вартість } \\
1 \mathrm{~m}^{2}\end{array}$} & \multirow{2}{*}{$\begin{array}{c}\text { Площа } \\
\text { 1-кімн. } \\
\text { квартири, } \\
\text { м² }^{2}\end{array}$} & \multicolumn{2}{|c|}{ Початковий внесок } \\
\hline & & & & $\%$ & грн \\
\hline \multirow[t]{2}{*}{ «Будінвест М» } & вул. Ляхова & $\begin{array}{l}10000 \\
9500 \\
9000 \\
\end{array}$ & 39 & $\begin{array}{c}30 \\
50 \\
100 \\
\end{array}$ & $\begin{array}{l}117000 \\
185250 \\
900000 \\
\end{array}$ \\
\hline & вул. Жовтнева, 60 д & 10000 & 39 & 100 & 390000 \\
\hline «Ельман» & вул. Коваля, 2 & 14400 & 60 & & \\
\hline «Новобуд-2004» & вул. Ватутіна, 36/11 & 7200 & 42,5 & 30 & 91800 \\
\hline $\begin{array}{c}\text { Полтавський домобу- } \\
\text { дівний комбінат }\end{array}$ & $\begin{array}{l}\text { вул. Петровського, } 37 \\
\text { (с. Щербані) }\end{array}$ & 6000 & 43 & & \\
\hline «Полтаватрансбуд» & $\begin{array}{l}\text { вул. Жовтнева, } 46 \text { в } \\
\text { вул. Сковороди, } 2 \text { в }\end{array}$ & $\begin{array}{l}14000 \\
10000\end{array}$ & $\begin{array}{l}46 \\
50 \\
40\end{array}$ & $\begin{array}{l}30 \\
30 \\
30\end{array}$ & \\
\hline
\end{tabular}

Авторська розробка

Іноземні будівельні компанії мало представлені на вітчизняному будівельному ринку, зокрема через складні й непрозорі процедури отримання дозвільних документів на здійснення будівництва, корупційні схеми під час виділення земельних ділянок, потребу працювати в умовах «відкатів» (хабарів) для чиновників. Ці ж фактори стримують і деякі потужні українські будівельні фірми (передусім столичні), які не наважуються працювати у регіонах.

За нинішньої системою будівництва житла покупець повинен зробити перший внесок (від 30 до $50 \%$ від вартості житла) ще на початку будівництва (як правило, на етапі підготовки котловану під будівництво майбутнього будинку). У таблиці наведено інформацію про основні умови покупки однокімнатної квартири у місті Полтава.

Дані таблиці свідчать про те, що сума початкового первинного внеску для покупки навіть однокімнатної квартири невеликої площі (квартири не преміум, а економ-класу) є занадто великою для більшості жителів міста. Однак складність проблеми не тільки у значній сумі початкового внеску, але й у схемі платежів. Тут дослідники виділяють три можливих варіанти: для тих покупців, що готові інвестувати 50-70 \% вартості житла, можлива виплата залишку у гривні по фіксованій ціні, прописаній в угоді. Другий варіант - прив'язка до курсу гривні на момент оплати. Третій - платежі, розмір яких буде зростати по мірі готовності будинку. Цей варіант використовується найчастіше. Забудовники пояснюють це тим, що у зв'язку з інфляцією та девальвацією гривні вони не можуть прогнозувати свої витрати. Їм простіше індексувати вартість житла відповідно до зростання витрат і таким чином застрахувати свої ризики.

Наступною значною проблемою сучасної системи будівництва нового житла $\epsilon$ відсутність контролю з боку покупця квартири за цільовим використанням коштів. Це особливо проявилося в умовах економічної кризи, що розпочалася 3 2008 році. Багато будівельних організацій, що мали кілька розпочатих об'єктів будівництва, потерпаючи від фінансових труднощів, почали використовувати грошові кошти, отримані на будівництво різних житлових будинків, для добудови одного. I як результат - ситуація, що склалася 3 покупцями квартир у м. Полтава в будинку по вулиці Станіславського, 2. Коли покупці квартир перерахували кошти за омріяне житло, забудовник, одночасно будуючи кілька об'єктів, завершив ті, що знаходилися на високій стадії готовності, не здолавши фінансові труднощі, збанкрутував. У результаті - люди внесли грошові кошти за квартири, забудовник перестав існувати, розпродаж його майна не покрив збитки кредиторів, будинок не збудований (тільки перший поверх і той не повністю перекритий). Ошукані вкладники вже кілька років звертаються до органів влади, вимагають повернення коштів або добудови будинка, але проблема не вирішується.

Суттєвим недоліком сучасної системи житлового будівництва $є$ абсолютне неврахування потреб певних категорій населення під час зведення багатоповерхового житлового будинку. 


\section{EKOHOMIKA}

Наприклад, інваліди-візочники не можуть виїхати 3 квартири, бо неможливо спускатися сходами, не передбачені заїзди-пандуси на вході до під’їду, високі дверні пороги, що неможливо переїхати, тощо). Бувають випадки, коли інвалідимешканці багатоповерхівки роками не можуть вийти на вулицю.

Висновок. Основними проблемами сучасної системи будівництва нового житла є високі ціни, корупція під час виділення земельних ділянок, реалізація забудовниками різних «тіньових» схем для штучного збільшення собівартості жит-

\section{БІБЛІОГРАФІЯ}

1. Костицьын П. Метры дорогие: что происходит с рынком недвижимости [Електронний ресурс] / П. Костицын. - Режим доступу : http://politica-ua.com/metry-dorogie-chto-proisxodits-rynkom-nedvizhimosti/?72771.

2. Рева Н. В 2014 году индекс недоступности жилья вырос вдвое [Електронний ресурс] / H. Рева. - Режим доступу : http://domik.ua/novosti /v-2014-godu-indeks-nedostupnosti-zhilya-vyrosvdvoe-n231842.html.

3. Дубенська О. Нерухомість у рік потрясінь [Електронний ресурс] / О. Дубенська. - Режим ла, відсутність контролю з боку покупця квартири за цільовим використанням коштів, система замовників, неврахування потреб певних категорій населення. Можна стверджувати, що серед них $є$ багато таких, що можуть бути вирішені якщо не повністю, то принаймні частково. I саме житлова кооперація (через запровадження житлово-будівельних кооперативів) може бути одним із можливих механізмів вирішення гострої житлової проблеми в Україні. Це є темою наступної наукової розробки.

доступу : http://economics.lb.ua/state/2014/12/27/ 290433 neruhomist_rik_potryasin.html.

4. Новосвитняя $\bar{E}$. Иван Салий: «Надо восстановить в столице квартирную очередь. Государство имеет моральные обязательства перед людьми, ожидающими жилье по 15-20 и более лет» / Е. Новосвитняя // Факты. - 2014. - 16 мая. C. 10 .

5. Средняя зарплата в Украине в октябре выросла на 28 грн. [Електронний ресурс]. - Режим доступу : http:/glavcom.ua/news/251526.html. 